\title{
The Human $D_{2}$ Dopamine Receptor Synergizes with the $A_{2 A}$ Adenosine Receptor to Stimulate Adenylyl Cyclase in $\mathrm{PCI} 2$ Cells
}

\author{
Oliver Kudlacek', Herwig Just', Vladimir M Korkhov', Nina Vartian', Markus Klinger', Halyna \\ Pankevych', Qiong Yang', Christian Nanoff', Michael Freissmuth*', and Stefan Boehm' \\ 'Institute of Pharmacology, University of Vienna, A- 1090 Wien, Austria
}

\begin{abstract}
The adenosine $A_{2 A}$ receptor and the dopamine $D_{2}$ receptor are prototypically coupled to $G_{s}$ and $G_{i} / G_{0}$, respectively. In striatal intermediate spiny neurons, these receptors are colocalized in dendritic spines and act as mutual antagonists. This antagonism has been proposed to occur at the level of the receptors or of receptor-G protein coupling. We tested this model in PCI2 cells which endogenously express $A_{2 A}$ receptors. The human $D_{2}$ receptor was introduced into $P C 12$ cells by stable transfection. $A_{2 A}$-agonistmediated inhibition of $\mathrm{D}_{2}$ agonist binding was absent in PCI2 cell membranes but present in HEK293 cells transfected as a control. However, in the resulting PCI 2 cell lines, the action of the $D_{2}$ agonist quinpirole depended on the expression level of the $D_{2}$ receptor: at low and high receptor levels, the $A_{2 A}$-agonist-induced elevation of CAMP was enhanced and inhibited, respectively. Forskolin-stimulated CAMP formation was invariably inhibited by quinpirole. The effects of quinpirole were abolished by pretreatment with pertussis toxin. $A_{2 A^{-}}$-receptor-mediated cAMP formation was inhibited by other $G_{i} / G_{0}$-coupled receptors that were either endogenously present $\left(P_{2 y \mid 2^{-}}\right.$ like receptor for ADP) or stably expressed after transfection ( $A_{1}$ adenosine, metabotropic glutamate receptor-7A). Similarly, voltage activated $\mathrm{Ca}^{2+}$ channels were inhibited by the endogenous $\mathrm{P}_{2 Y}$ receptor and by the heterologously expressed $A_{1}$ receptor but not by the $D_{2}$ receptor. These data indicate functional segregation of signaling components. Our observations are thus compatible with the proposed model that $D_{2}$ and $A_{2 A}$ receptors are closely associated, but they highlight the fact that this interaction can also support synergism.
\end{abstract}

Neuropsychopharmacology (2003) 28, 1317-1327, advance online publication, 30 April 2003; doi: I0.1038/sj.npp. I300 I8I

Keywords: $A_{2 A}$ adenosine receptor; $D_{2}$ dopamine receptor; adenylyl cyclase isoforms; voltage-activated $\mathrm{Ca}^{2+}$ channel; rap I

\section{INTRODUCTION}

In the central nervous system, adenosine and dopamine act as neuromodulators that bind to G-protein-coupled receptors and impinge on fast synaptic transmission by inhibitory and excitatory amino acids. Both the $\mathrm{G}_{s} / \mathrm{G}_{\text {olf }}-$ coupled $A_{2 A}$ adenosine receptor and the $G_{i} / G_{0}$-coupled $D_{2}$ dopamine receptor are enriched in the corpus striatum and in mesolimbic areas, such as the nucleus accumbens and the lateral septum (Svenningsson et al, 1999). In these brain regions, the two receptors are mostly colocalized, and various types of interactions between $A_{2 A}$ and $D_{2}$ receptor ligands reveal a functional link between these two proteins: (i) Blockage of $\mathrm{D}_{2}$ receptors (eg by neuroleptic drugs or by

\footnotetext{
*Correspondence: Dr M Freissmuth, Institute of Pharmacology, University of Vienna, Waehringer Str.13A, A-1090 Wien, Austria, Tel: + 43 | 4277 64l7I, Fax: + 43 | 4277 964I,

E-mail: michael.freissmuth@univie.ac.at

Received 22 May 2002; revised 10 February 2003; accepted 20 February 2003

Online publication: 27 February 2003 at http://www.acnp.org/citations/ Npp0227021 97/default.pdf
}

targeted knockout of the gene) or depletion of dopamine impairs locomotion, and this dysfunction can be ameliorated by the administration of $\mathrm{A}_{2 \mathrm{~A}}$ antagonists (see Aoyama et al, 2000; Grondin et al, 1999; earlier references in Richardson et al, 1997). (ii) Activation of $\mathrm{A}_{2 \mathrm{~A}}$ receptors induces catalepsy (Ferré et al, 1991a) as do $\mathrm{D}_{2}$ antagonists. Conversely, catalepsy induced by blockage of $\mathrm{D}_{2}$ receptors is reversed by $\mathrm{A}_{2 \mathrm{~A}}$ antagonists (Hauber et al, 2001). (iii) The induction of the immediate-early gene c-fos by $\mathrm{D}_{2}$ antagonists is attenuated by blockage of $\mathrm{A}_{2 \mathrm{~A}}$ receptors; this effect is confined to neurons where the receptors are coexpressed (Pinna et al, 1999). Taken together, these results indicate that there is a functional antagonism between $\mathrm{A}_{2 \mathrm{~A}}$ and $\mathrm{D}_{2}$ receptors (Ferré et al, 1997). In line with these experimental data, both retrospective epidemiological evidence (Fredholm et al, 1999; Benedetti et al, 2000 and references therein) as well as prospective cohort studies (Ross et al, 2000; Ascherio et al, 2001) indicate that blockage of $\mathrm{A}_{2 \mathrm{~A}}$ receptors by caffeine intake reduces the risk of people to develop Parkinson's disease. Similarly, the adenosine uptake inhibitor dipyridamol enhances the antipsychotic activity of the $\mathrm{D}_{2}$ antagonist haloperidol 
(Akhondzadeh et al, 2000). Thus, $\mathrm{A}_{2 \mathrm{~A}}$ receptor ligands have been recognized as novel therapeutic agents for illnesses typically treated with $\mathrm{D}_{2}$ receptor ligands.

The functional antagonism between $\mathrm{D}_{2}$ and $\mathrm{A}_{2 \mathrm{~A}}$ receptors has been proposed to reflect the ability of the $A_{2 A}$ receptor to impair high-affinity agonist binding to the $\mathrm{D}_{2}$ receptor by a membrane-delimited process. This effect was originally observed in rat striatal membranes (Ferré et al, 1991b), and subsequently also documented upon heterologous expression of the receptors in fibroblast cell lines (Ltk-murine fibroblasts in Dasgupta et al, 1996; Chinese hamster ovary cells in Kull et al, 1999). Agonist occupancy of the $A_{2 A}$ receptor blunted high-affinity agonist binding to the $D_{2}$ receptor in the absence of GTP; hence, the effect was proposed to be accounted for by an interaction at the level of the receptors or of receptor $-\mathrm{G}$ protein complexes. While this model explains the antagonistic action of the $A_{2 A}$ adenosine receptor, several observations, however, cannot be accounted for by simple reciprocal antagonism at the level of these two receptors. Most importantly, mice lacking $\mathrm{A}_{2 \mathrm{~A}}$ receptors display a hypodopaminergic phenotype (Dassesse et al, 2001); similarly, stimulation of the striatal $\mathrm{A}_{2 \mathrm{~A}}$ receptor fails to elevate cAMP in mice that are deficient in $\mathrm{D}_{2}$ receptors (Zahniser et al, 2000). These findings may reflect adaptive changes that occur during development to cope with the targeted deletion of the respective genes. Alternatively, they may indicate that the interaction between the $A_{2 A}$ receptor and the $D_{2}$ receptor is not solely mutually antagonistic. In the present work, we employed the neuroendocrine cell line PC12 to examine effector regulation by the combined stimulation of the $A_{2 A}$ adenosine and $\mathrm{D}_{2}$ dopamine receptor. PC12 cells can be differentiated into a neuronal phenotype by nerve growth factor. Our results demonstrate that $\mathrm{D}_{2}$ receptors can synergize with $A_{2 A}$ receptors to stimulate cAMP accumulation, a property that is not shared by other $G_{i} / G_{o}$-coupled receptors.

\section{MATERIAL AND METHODS}

\section{Materials}

PC12 cells were obtained from the European Collection of Cell Cultures (ECACC; Salisbury, UK). Collagen was from Biomedical Technologies Inc. (Stoughton, MA, USA). Human $\beta$-nerve growth factor (NGF) was from R\&D Systems Inc. (Wiesbaden, Germany). Adenosine deaminase was from Roche Molecular Biochemicals (Mannheim, Germany). Optimem medium, L-glutamine, penicillin G, streptomycin, horse serum, fetal calf serum (FCS), and G418 (geneticin) were from Life Technologies (Grand Island, NY). Centrifuge tubes and tissue culture plates were from Greiner (Vienna, Austria) and from Corning Costar (Acton, MA). $\left[{ }^{3} \mathrm{H}\right]$ adenine, $\left[{ }^{3} \mathrm{H}\right] \mathrm{CCPA}$ (CCPA, 2-chloro-CPA), $\left[{ }^{3} \mathrm{H}\right] \mathrm{ZM} 241385$ (ZM241385, 4-(2-[7-amino-2-(2-furyl)[1,2, $3]$ triazolo[2,3-a] [1,3,5]triazin-5-ylamino]ethyl)phenol), and $\left[{ }^{125} \mathrm{I}\right] \mathrm{OH}-\mathrm{PIPAT}$ (OH-PIPAT, (Rs)-trans-8-hydroxy-2[ $N$-propyl- $N$-( $3^{\prime}$-iodo-2'-propenyl) amino]tetralin) were from New England Nuclear (Boston, MA), and $\left[{ }^{125} \mathrm{I}\right]$ epidepride was from the Austrian Research Centre (Seibersdorf, Austria). Forskolin, RO201724 (DL-4-(3-butoxy-4-methoxybenzoyl)-2-imidazolodione), xanthine amine congener
(XAC), haloperidol, and pertussis toxin were purchased from Sigma Chemical Co. (St Louis, MO), and CGS21680 (2[ $p$-(2-carboxyethyl)phenethylamino]- $5^{\prime}-N$-ethylcarboxamidoadenosine) from Tocris (Bristol, UK). Affinity-purified rabbit antiserum against rap1/Krev-1 was from Santa Cruz Biotechnology (Santa Cruz, CA). Immunofluorescence was performed with anti-c-myc antibody (Santa Cruz Biotechnology), anti-FLAG antibody M2 (Stratagene, La Jolla, CA), anti-HA antibody 16B12 (kind gift of E Ogris, Vienna Biocenter), Cy3-coupled goat anti-rabbit (Amersham, Buckinghamshire, UK), and FITC-coupled goat anti-mouse (Jackson, West Grove, PA).

\section{Cell Culture and Transfection}

PC12 cells were plated onto collagen-coated culture dishes (Biomedical Technologies Inc., Stoughton, MA, USA), propagated in Opti-Mem medium containing 10\% (vol/ vol) horse serum, 5\% (vol/vol) FCS, $0.2 \mathrm{mM}$ L-glutamine, $25000 \mathrm{U} / \mathrm{l}$ penicillin $\mathrm{G}$, and $25 \mathrm{mg} / \mathrm{l}$ streptomycin. Media for culture of stably transfected cells were supplemented with $0.2 \mathrm{mg} / \mathrm{ml}$ geneticin (G418) in order to maintain the selection pressure. Transfection of $\mathrm{PC} 12$ cells and of HEK293 was performed using lipofection (TransFast ${ }^{\circledR}$, Promega, Madison, WI) and $\mathrm{CaPO}_{4}$-precipitation, respectively. The plasmids employed encoded the wild type and epitope-tagged versions of the human $\mathrm{D}_{2}$ dopamine (BofillCardona et al, 2000), the FLAG-tagged metabotropic glutamate receptor-7A (mGluR7A) (ElFar et al, 2001), the c-myc-tagged human $\mathrm{A}_{2 \mathrm{~A}}$ adenosine receptor (Klinger et al, 2002), and the HA-tagged $A_{1}$ adenosine receptor; the latter was generated by PCR using a primer that extended the $\mathrm{N}$ terminus by the nine amino acids (YPYDVPDYA) that represent the major epitope of influenza hemaglutinin. The integrity of the coding sequence was verified by fluorescent sequencing. After $48 \mathrm{~h}$, geneticin (G418; $0.8 \mathrm{mg} / \mathrm{ml}$ ) was added to the media to initiate selection for stably transfected cells. Receptor expression was checked by binding $\left(\left[{ }^{3} \mathrm{H}\right] \mathrm{CCPA}\right.$ for the $\mathrm{A}_{1}$ receptor; $\left[{ }^{125} \mathrm{I}\right]$ epidepride for the $\mathrm{D}_{2}$ receptor) or by immunofluorescence (in particular mGluR7A because a suitable radioligand is not available). Nontransfected PC12 cells did not contain detectable amounts of $A_{1}$ and $D_{2}$ receptors (detection limit $<10 \mathrm{fmol} / \mathrm{mg}$ ) and did not respond to any of the receptor agonists $\left(\mathrm{A}_{1}=\mathrm{CPA}\right.$ or $\mathrm{R}$-PIA, $\mathrm{D}_{2}=$ quinpirole, mGluR7A = L-AP4) employed. (CPA, N6-cyclopentyladenosine;L-AP4 = L-2-amino-4-phosphonobutanoic acid.)

Prior to the recording of $I_{\mathrm{Ca}}, \mathrm{PC} 12$ cells were detached from culture dishes and replated at low density. In order to induce neuronal differentiation, PC12 cells were exposed to recombinant human NGF $(50 \mathrm{ng} / \mathrm{ml})$ for $5-6$ days.

\section{Membrane Preparation and Receptor Binding}

Cells were harvested and membranes were prepared as previously described (Waldhoer et al, 1998). The final membrane pellet was resuspended in buffer $(25 \mathrm{mM}$ Hepes. $\mathrm{NaOH}, \mathrm{pH} 7.5,1 \mathrm{mM}$ EDTA, $2 \mathrm{mM} \mathrm{MgCl}_{2}$ ) at a protein concentration of $8-10 \mathrm{mg} / \mathrm{ml}$ and stored in aliquots at $-80^{\circ} \mathrm{C}$. Binding of $\left[{ }^{3} \mathrm{H}\right] \mathrm{CCPA}$ was carried out in $80 \mu \mathrm{l}$ buffer (25 mM Tris-HCl, pH 8, $1 \mathrm{mM}$ EDTA, $5 \mathrm{mM} \mathrm{MgCl}_{2}$ ) 
containing $8 \mathrm{mg} / \mathrm{ml}$ adenosine deaminase and cell membranes $(8-10 \mu \mathrm{g} /$ assay). Nonspecific binding was determined in the presence of $10 \mu \mathrm{M}$ CPA. Binding of $\left[{ }^{3} \mathrm{H}\right] \mathrm{ZM} 241385$ and of $\left[{ }^{125} \mathrm{I}\right]$ epidepride was done in $200 \mu \mathrm{l}$ and $40 \mu \mathrm{l}$ of the same buffer, respectively, containing cell membranes $(60-70 \mu \mathrm{g}$ and $8-10 \mu \mathrm{g} /$ assay, respectively); nonspecific binding was determined in the presence of $10 \mu \mathrm{M}$ XAC $\left(\mathrm{A}_{2 \mathrm{~A}}\right.$ antagonist binding) or of $3 \mu \mathrm{M}$ sulpiride $\left(\mathrm{D}_{2}\right.$ antagonist binding). For binding of $\left[{ }^{125} \mathrm{I}\right] \mathrm{OH}-\mathrm{PIPAT}$, the assay volume was $50 \mu \mathrm{l}$ and the membrane protein concentration was $15-20 \mu \mathrm{g} /$ assay. Nonspecific binding was determined in the presence of $5 \mu \mathrm{M}$ haloperidol. All binding experiments were done at $25^{\circ} \mathrm{C}$ for $90 \mathrm{~min}$ and stopped by filtration over glass fiber filters.

\section{Accumulation of cAMP}

The adenine nucleotide pool of PC12 cells was metabolically prelabeled for $16 \mathrm{~h}$ with $\left[{ }^{3} \mathrm{H}\right]$ adenine $(1 \mu \mathrm{Ci} /$ well $)$ in Optimem containing $1 \%(\mathrm{vol} / \mathrm{vol})$ horse serum and $1 \mathrm{U} / \mathrm{ml}$ adenosine deaminase as outlined previously (Kudlacek $e t a l$, 2001). After the preincubation, fresh medium was added that contained adenosine deaminase $(1 \mathrm{U} / \mathrm{ml})$ and $100 \mu \mathrm{M}$ RO201724; 30 min later, cAMP formation was stimulated by the $A_{2 A}$ selective agonist CGS21680 $(1 \mu \mathrm{M}$, if not otherwise indicated) or by $25 \mu \mathrm{M}$ forskolin for $15 \mathrm{~min}$ in the absence and presence of agonists for the $G_{i} / G_{o}$-coupled receptors (quinpirole, $\mathrm{ADP} \beta \mathrm{S}, \mathrm{ADP}, \mathrm{CPA}, \mathrm{L}-\mathrm{AP} 4$; see figures for concentrations). Assays were performed in triplicate. The formation of $\left[{ }^{3} \mathrm{H}\right]$ cAMP was determined according to Salomon (1991).

\section{Pull-Down Assay for the Determination of Rap1- Activation}

The GST fusion protein comprising the rap1-binding domain of ralGDS (ral-RBD, Franke et al, 1997) was expressed in E. coli (strain BL21DE3) and used to trap GTP-loaded rap1 as described (Seidel et al, 1999). Cells were prepared for the assay in a similar way as for accumulation of cAMP (serum withdrawal for $16 \mathrm{~h}$ in the presence of adenosine deaminase followed by replacement by fresh medium containing adenosine deaminase). Subsequently cells were incubated with CGS21680 or vehicle for $5 \mathrm{~min}$. The amount of recovered GTP-liganded rap1 was quantified by scanning immunoblots using a BioRad GelDoc1000 and Molecular Analyst software.

\section{Electrophysiology}

Voltage-activated $\mathrm{Ca}^{2+}$ currents were determined as described before (Vartian and Boehm, 2001). Prior to the recording of $\mathrm{I}_{\mathrm{Ca}}$, PC12 cells were detached from culture dishes and replated at low density. Whole-cell currents were recorded at room temperature $\left(20-24^{\circ} \mathrm{C}\right)$ from $\mathrm{PC} 12$ cells $24-48 \mathrm{~h}$ after replating at low density, using an Axopatch 200B amplifier and the Pclamp 6.0 hard- and software (Axon Instruments, Foster City, CA, USA). Currents were low-pass filtered at $5 \mathrm{kHz}$, digitized at $50 \mathrm{kHz}$, and stored on an IBM-compatible computer. Traces were analyzed off-line by the Clampfit program (Axon). Patch electrodes were pulled (Flaming-Brown puller, Sutter Instruments, Novato,
CA, USA) from borosilicate glass capillaries (Science Products, Frankfurt/Main, Germany) and filled with a solution consisting of (mM) CsCl (130), tetraethylammonium chloride (20), $\mathrm{CaCl}_{2}$ (0.24), glucose (10), HEPES (10), EGTA (5), Mg-ATP (2), and Li-GTP (2), adjusted to pH 7.3 with $\mathrm{KOH}$, to yield tip resistances of $2-3 \mathrm{M} \Omega$. The external bathing solution consisted of (mM) $\mathrm{NaCl}$ (120), tetraethylammonium chloride (20), $\mathrm{KCl}(3), \mathrm{MgCl}_{2}$ (2), $\mathrm{CaCl}_{2}$ (5), glucose (20), HEPES (10), adjusted to pH 7.3 with KOH. Drugs were applied via a DAD-12 drug application device (Adams \& List, Westbury, NY, USA), which permits a complete exchange of solutions surrounding the cells under investigation within less than $100 \mathrm{~ms}$ (see Vartian and Boehm, 2001). To evaluate the effects of receptor agonists, PC12 cells were exposed to these agents for at least $30 \mathrm{~s}$. Unless otherwise indicated, whole-cell $\mathrm{Ca}^{2+}$ currents were elicited by $30 \mathrm{~ms}$ depolarizations from a holding potential of $-80 \mathrm{mV}$ to $0 \mathrm{mV}$ at a frequency of $4 \mathrm{~min}^{-1}$.

$I_{\mathrm{Ca}}$ was quantified by measuring peak current amplitudes during the depolarization to $0 \mathrm{mV}$. To account for timedependent changes in $\mathrm{Ca}^{2+}$ current amplitudes, drug effects were evaluated by evoking currents in the presence of test drugs $(B)$ and by comparing them to control currents recorded before $(A)$ and after (washout, $C$ ) the application of the drugs, according to the equations: $200 * B /(A+C)=\%$ of control current, or $100-(200 * B /[A+C])=\%$ inhibition (see Vartian and Boehm, 2001). Significance of differences between single data points was evaluted by the MannWhitney test.

If not otherwise indicated, all experiments were carried out at least three times and means $\pm S D$ are reported.

\section{RESULTS}

\section{Heterologous Expression of G Protein-Coupled Receptors in PC12 Cells}

The rat pheochromocytoma cell line PC12 can be differentiated to adopt a neuron-like phenotype. In addition, PC12 cells endogenously express $\mathrm{A}_{2 \mathrm{~A}}$ adenosine receptors. We therefore used this cell line as a model system to study the interaction of $\mathrm{A}_{2 \mathrm{~A}}$ and $\mathrm{D}_{2}$ receptors. The latter was introduced by stable transfection $\left(\mathrm{PC} 12-\mathrm{D}_{2}\right)$, because we were unable to detect appreciable levels of $\mathrm{D}_{2}$ receptors in PC12 cell lines from two different sources (data not shown). After stable transfection, cell clones were isolated that expressed $D_{2}$ receptors at levels ranging from 20 to $1500 \mathrm{fmol} / \mathrm{mg}$. A representative saturation experiment is shown in Figure 1a, where membranes from a clone that expressed $60 \mathrm{fmol} / \mathrm{mg}$ were incubated with the high-affinity $\mathrm{D}_{2}$ antagonist $\left[{ }^{125} \mathrm{I}\right]$ epidepride $\left(K_{\mathrm{D}}=25 \pm 5 \mathrm{pM}\right)$. The estimated $B_{\max }$ values covered the range of density of $\mathrm{D}_{2}$ dopamine receptors labeled by $\left[{ }^{125} \mathrm{I}\right]$ epidepride in striatal membranes (120-160 fmol/mg; Beindl et al, 1996). The expression level of the endogenous $A_{2 a}$ adenosine receptor in these cells was determined with an $\mathrm{A}_{2 \mathrm{~A}}$-selective antagonist; a $B_{\max }$ of $1.6 \pm 0.2 \mathrm{pmol} / \mathrm{mg}$ was estimated from saturation isotherms for the binding of $\left[{ }^{3} \mathrm{H}\right] \mathrm{ZM} 241385$ to membranes of PC12- $\mathrm{D}_{2}$ cells (Figure 1c). This was reasonably similar to the amount of receptors detected in parallel in striatal membranes $\left(B_{\max }=0.9 \pm 0.1 \mathrm{pmol} / \mathrm{mg}\right.$; data not shown). 
a

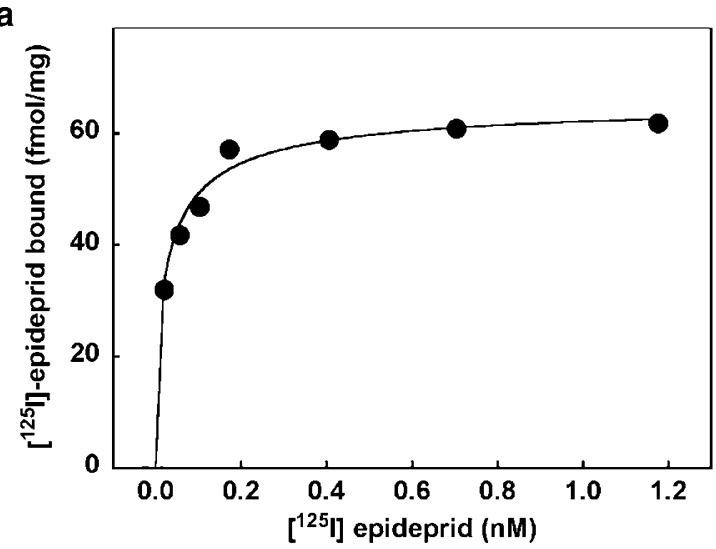

b
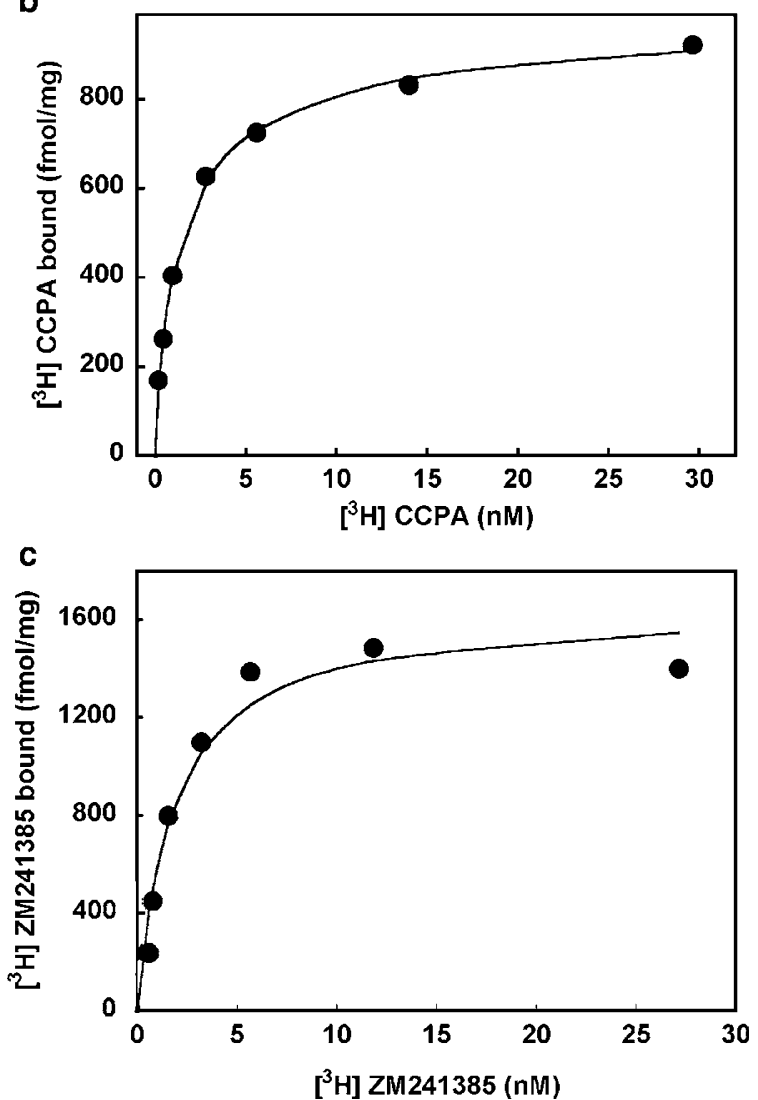

Figure I Radioligand binding to membranes from $\mathrm{PCl} 2$ cells stably transfected with plasmids driving the expression of $D_{2}$ dopamine $(a, c)$ and $A_{1}$ adenosine (b) receptors. Binding of the $D_{2}$ antagonist [ $\left.{ }^{125} \mid\right]$ epidepride (a) and of the $A_{1}$ agonist $\left[{ }^{3} \mathrm{H}\right]$ CCPA (b) was determined using membranes ( $10 \mu \mathrm{g} /$ assay) prepared from stably transfected cells. Endogenous $A_{2 A}$ adenosine receptor expression level was determined with the $A_{2 A}$ antagonist $\left[{ }^{3} \mathrm{H}\right] \mathrm{ZM} 24 \mathrm{I} 385$ (c) in membranes (70 $\mu \mathrm{g}$ /assay) prepared from stably transfected $\mathrm{PCI} 2$ cells expressing the $\mathrm{D}_{2}$ receptor. Assay conditions were as outlined under 'Materials and methods'. Data are from a representative experiment that was carried out in duplicate and reproduced three times.

In order to carry out control experiments (see below), two additional $G_{i / o}$-coupled receptors, namely the $A_{1}$ adenosine receptor and the mGluR7A, were expressed in PC 12 cells and stable cell lines were generated. The expression level of the $A_{1}$ adenosine receptor was determined by binding of the high-affinity $A_{1}$ agonist $\left[{ }^{3} \mathrm{H}\right] \mathrm{CCPA}$ to membranes of PC12 cells; a cell clone was selected that expressed about $1 \mathrm{pmol} /$ mg (Figure $1 \mathrm{~b}$ ); that is, the membrane levels of this receptor was within the range at which this receptor is typically expressed in brain membranes of most species, including man (Jockers et al, 1994). Cell lines were also generated that expressed the group III mGluR7A. A suitable radioligand is not available for this receptor. Hence, the expression of this receptor was monitored by staining the cells for membraneassociated immunoreactivity. The rationale for employing mGluR7A is the fact that this receptor is specifically targeted to presynaptic specializations (Shigemoto et al, 1996; Stowell and Craig, 1999). Hence, the use of mGluR7A allowed to gauge the capacity of PC12 cells to support a spatial segregation of a receptor by sorting and targeting. Upon NGF-induced differentiation of PC12 cells, mGluR7A was indeed delivered to the tips of the extending neurites (data not shown).

Effect of the $\mathrm{A}_{2 \mathrm{~A}}$ Adenosine Receptor Agonist CGS21680 on High-Affinity Binding of $\mathrm{D}_{2}$ Receptor Agonists and Antagonists to Membranes of PC12 cells Heterologously Expressing the $\mathrm{D}_{2}$ Dopamine Receptor

Stimulation of $\mathrm{A}_{2 \mathrm{~A}}$ adenosine receptors impedes highaffinity agonist binding to the $\mathrm{D}_{2}$ dopamine receptor by blocking the formation of ternary complexes of agonist, receptor, and $\mathrm{G}$ protein; this functional antagonism between $A_{2 A}$ receptor and $D_{2}$ receptor has been reported for various cell systems including striatal membranes (Ferré et al, 1991b), Ltk-murine fibroblasts (Dasgupta et al, 1996), and Chinese hamster ovary (CHO) cells (Kull et al, 1999). We therefore tested the effects of the $A_{2 A}$ agonist CGS21680 on the binding of the $\mathrm{D}_{2}$ agonist $\left[{ }^{125} \mathrm{I}\right] \mathrm{OH}-\mathrm{PIPAT}$ to membranes from the PC12 cell clone in which $B_{\max }$ for the antagonist $\left[{ }^{125} \mathrm{I}\right]$ epidepride amounted to $\sim 60 \mathrm{fmol} / \mathrm{mg}$ (Figure 2a). In the absence of CGS21680 (open circles, Figure $2 \mathrm{a}),\left[{ }^{125} \mathrm{I}\right] \mathrm{OH}-\mathrm{PIPAT}$ bound with high affinity to about $40 \%$ of the $\mathrm{D}_{2}$ dopamine receptors $\left(B_{\max }=26 \pm 5 \mathrm{f}\right.$ $\mathrm{fmol} / \mathrm{mg}$ ) that were labeled by the antagonist (cf Figure 1a). Addition of CGS 21680 (closed circles in Figure 2a) did not affect the $B_{\max }$ or the $K_{\mathrm{D}}(0.65 \pm 0.13$ and $0.59 \pm 0.11 \mathrm{nM}$ in the absence and presence of CGS21680, respectively) for binding of $\left[{ }^{125} \mathrm{I}\right] \mathrm{OH}-\mathrm{PIPAT}$. These findings differ from the observations reported for transfected fibroblast cell lines (Dasgupta et al, 1996; Kull et al, 1999), where the $\mathrm{A}_{2 \mathrm{~A}}$ agonist impedes ternary complex formation by the agonistliganded $D_{2}$ receptor. We therefore also expressed the $A_{2 A}$ adenosine receptor and $D_{2}$ dopamine receptor in HEK293 cells, a human fibroblast line. As can be seen from Figure $2 c$, in membranes prepared from these cells, CGS21680 did cause a loss of high-affinity agonist binding; it is evident that the $\mathrm{A}_{2 \mathrm{~A}}$ agonist inhibits binding of $\left[{ }^{125} \mathrm{I}\right] \mathrm{OH}-\mathrm{PIPAT}$ in a noncompetitive manner $\left(K_{\mathrm{D}}=0.72 \pm 0.07\right.$ and $0.91 \pm 0.26 \mathrm{nM} ; B_{\max }=66 \pm 8$ and $\left.39 \pm 6 \mathrm{fmol} / \mathrm{mg}\right)$. This loss of ternary complexes (of agonist, receptor, and $G$ protein) is to be expected if $A_{2 A}$ receptor stimulation blunts coupling of $\left[{ }^{125} \mathrm{I}\right] \mathrm{OH}-\mathrm{PIPAT}$-liganded $\mathrm{D}_{2}$ receptor to the $\mathrm{G}$ protein (Dasgupta et al, 1996; Kull et al, 1999). The $\mathrm{A}_{2 \mathrm{~A}}$ agonist does not interfere with ligand binding to the $\mathrm{D}_{2}$ receptor; in fact, when tested on binding of the antagonist $\left[{ }^{125} \mathrm{I}\right]$ epidepride, addition of $1 \mu \mathrm{M}$ CGS21680 did not alter binding $\left(K_{\mathrm{D}}=18.9 \pm 4 \mathrm{pM}\right.$ and $16.5 \pm 2 \mathrm{pM}$ in the absence and presence of CGS21680 in paired experiments; data not 
a

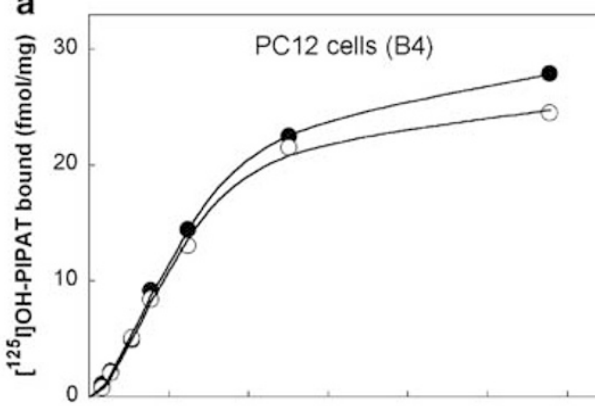

$\left[{ }^{125}\right.$ ] OH-Pipat $(\mathrm{nM})$

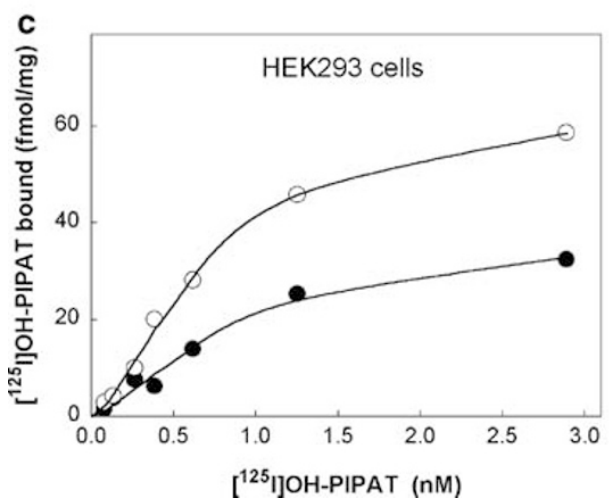

b

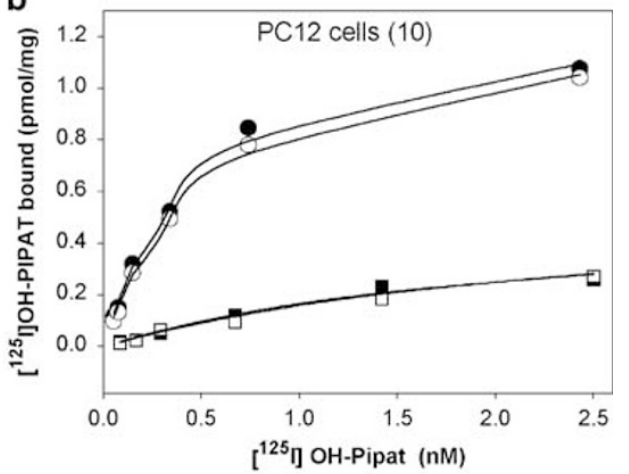

d

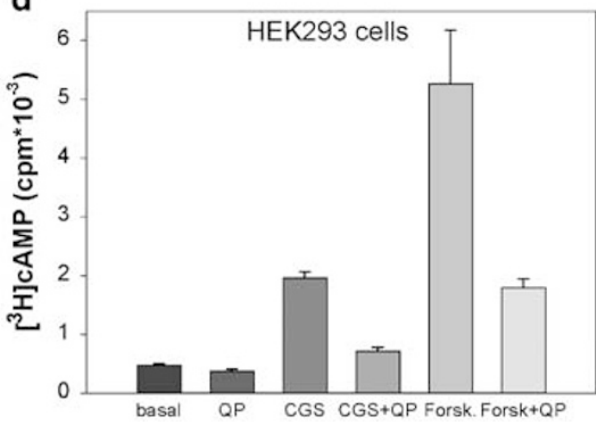

Figure 2 Effects of the $A_{2 A}$ adenosine agonist CGS 21680 on $D_{2}$ agonist binding to membranes from PCI 2 cells expressing the $D_{2}$ receptor at different levels (a, b) or HEK293 cells (c) expressing the $D_{2}$ and the $A_{2 A}$ receptor and cAMP accumulation in HEK293 cells (d). Binding of the $D_{2}$ agonist $[25$ I]OHPIPAT was determined in the absence (open circles) and presence (full symbols) of I $\mu$ M CGS2 I 680 or of I $00 \mu M$ GTP $\gamma s$ (squares in b) using membranes (20-30 $\mu$ g/assay) prepared from stably transfected PCI 2 cells (a, b) and HEK293 cells (c). Assay conditions were as outlined under 'Materials and methods'. Data are from representative experiments that were carried out in duplicate and reproduced three times. (d) The adenine nucleotide pool was metabolically labeled by preincubating transfected HEK293 cells with $\left[{ }^{3} \mathrm{H}\right]$ adenine $(I \mu \mathrm{Ci} / \mathrm{ml})$. Under basal conditions, the cells were maintained in the presence of adenosine deaminase $(\mathrm{I} / \mathrm{ml})$ and the phosphodiesterase inhibitor RO20 I 724 (I00 $\mu \mathrm{M}$ ) or stimulated for I5 min with I $\mu$ M CGS2 I680 (CGS) or $25 \mu \mathrm{M}$ forskolin (Forsk), $0.1 \mu \mathrm{M}$ quinpirole (QP), or the combination thereof as indicated.

shown). Finally, it is worth noting that the $A_{2 \mathrm{~A}}$ receptor levels in HEK293 cells were not higher than those observed in PC12 cells $\left(B_{\max }=0.4-0.7 \mathrm{pmol} / \mathrm{mg}\right.$; see also Klinger et al, 2002). Nevertheless, in PC12 cells the levels of the $D_{2}$ receptors may have been too low to be subject to modulation by the $\mathrm{A}_{2 \mathrm{~A}}$ agonist. We therefore investigated PC12 cell clones that expressed $\mathrm{D}_{2}$ receptors at different levels (covering the range of $60 \mathrm{fmol} / \mathrm{mg}$ to $1.3 \mathrm{pmol} / \mathrm{mg}$ ). Figure $2 \mathrm{~b}$ shows that - even at the highest membrane concentration of $\mathrm{D}_{2}$ receptor - the $\mathrm{A}_{2 \mathrm{~A}}$ agonist did not modulate $B_{\max }(1.31 \pm 0.06$ and $1.29 \pm 0.05 \mathrm{pM} / \mathrm{mg})$ or the $K_{\mathrm{D}}$ for $\left.{ }^{125} \mathrm{I}\right] \mathrm{OH}-\mathrm{PIPAT}(0.48 \pm 0.05$ and $0.53 \pm 0.05 \mathrm{nM}$ in the absence and presence of CGS21680, respectively). Finally, we also assessed the ability of the hydrolysisresistant GTP analogue GTP $\gamma$ S to destabilize the ternary complex in the presence and absence of CGS21680. It is evident that high-affinity agonist binding was suppressed to a similar extent by GTP $\gamma \mathrm{S}$ regardless of whether the $\mathrm{A}_{2 \mathrm{~A}}$ agonist was present or absent (Figure 2b, open and closed squares). Similar findings were obtained in three other PC12 cell clones (not shown).

\section{Cyclic AMP Formation of PC12 Cells Heterologously Expressing the $\mathrm{D}_{2}$ Receptor}

PC12 cells are notorious for their genetic instability; accordingly, a substantial variability of individual PC12 cell lines has been observed, if individual cell clones were investigated with respect to their complement of $A_{2 A}$ adenosine receptor, $\mathrm{G} \alpha_{\mathrm{s}}$ and adenylyl cyclase and with respect to $\mathrm{A}_{2 \mathrm{~A}}$-agonist-mediated cAMP increases (Arslan et al, 1999). In the clones employed in the present work, the $\mathrm{A}_{2 \mathrm{~A}}$ agonist CGS21680 gave a robust stimulation of cAMP levels ( $E_{\max }=\sim 4-8$-fold over basal levels; $\mathrm{EC}_{50}=25$ $50 \mathrm{nM}$; see Figure 4c). Activation of the $\mathrm{D}_{2}$ dopamine receptor was expected to inhibit adenylyl cyclase via $G_{i} / G_{0}-$ dependent signaling and to thereby blunt the stimulatory action of the $\mathrm{A}_{2 \mathrm{~A}}$ agonist. However, if the $\mathrm{D}_{2}$ agonist quinpirole was added to $\mathrm{PC} 12$ cells that expressed $\mathrm{D}_{2}$ receptors at $\sim 60 \mathrm{fmol} / \mathrm{mg}$ in the presence of a saturating concentration of CGS21680 $(1 \mu \mathrm{M})$, the level of cAMP was further augmented by about $30 \%$ (circles in Figure 3a). The $\mathrm{EC}_{50}$ of quinpirole for this effect was $4.0 \pm 1.2 \mathrm{nM}$. This potentiation was also seen with a second (independent, stably transfected) cell clone that expressed lower levels of $\mathrm{D}_{2}$ receptor $(20 \mathrm{fmol} / \mathrm{mg}$, closed squares in Figure $3 \mathrm{~b})$; conversely, quinpirole did not elicit any effect on PC12 cells that did not express the $\mathrm{D}_{2}$ dopamine receptor (not shown). Alternatively, cAMP accumulation was triggered by direct activation of adenylyl cyclase in the presence of $25 \mu \mathrm{M}$ forskolin; this concentration resulted in cAMP levels that were reasonably similar to those triggered by saturating CGS21680 (see Figure 4a and b and Kudlacek et al, 2001). Addition of quinpirole inhibited the forskolin-stimulated 


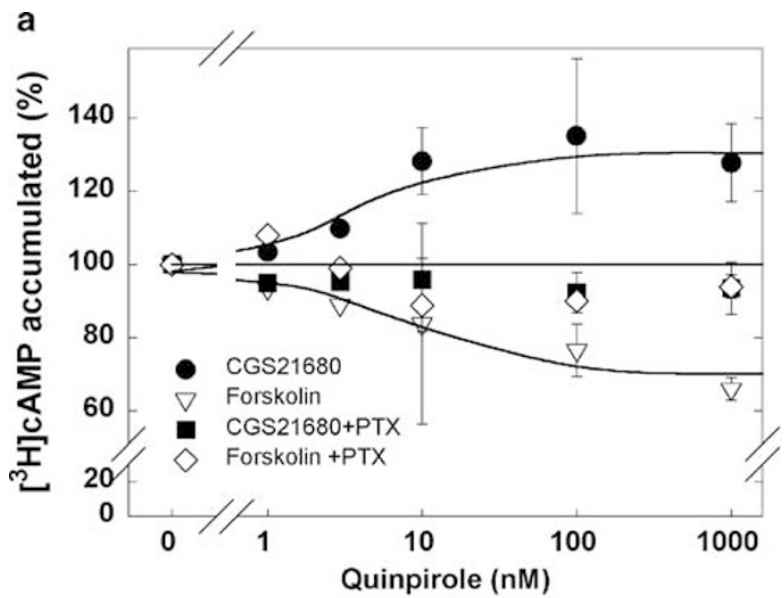

c
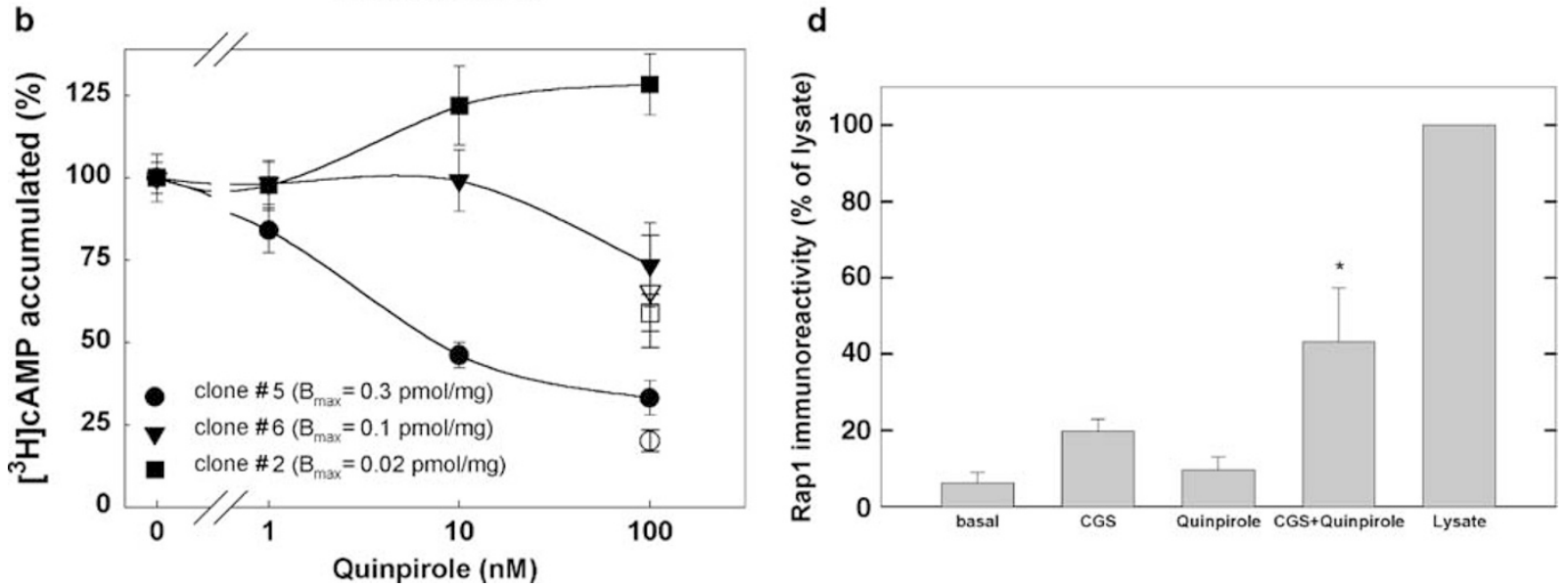

Figure 3 Cyclic AMP accumulation ( $a, b)$ and rap I activation (c, d) by combined stimulation of the $A_{2 A}$ and the $D_{2}$ receptor in $P C 12$ cells stably expressing the human $D_{2}$ receptor. (a) Cells expressing $60 \mathrm{fmol} / \mathrm{mg} \mathrm{D}_{2}$ receptors were maintained for $36 \mathrm{~h}$ in medium (circles and triangles) or pretreated for $36 \mathrm{~h}$ with $100 \mathrm{ng} / \mathrm{ml}$ pertussis toxin (squares and diamonds). In the last $16 \mathrm{~h}{ }^{3} \mathrm{H}$ ]adenine $(\mathrm{I} \mu \mathrm{Ci} / \mathrm{ml}$ ) was added to metabolically label the adenine nucleotide pool; thereafter, the cells were preincubated for $30 \mathrm{~min}$ with RO20I724 (I00 $\mu \mathrm{M}$ ) and adenosine deaminase (I U/ml) and subsequently stimulated for 15 min with I $\mu$ M CGS2 1680 (circles and squares) or $25 \mu \mathrm{M}$ forskolin (triangles and diamonds) and the indicated concentrations of quinpirole. Data are means \pm SD from three independent experiments that were performed in triplicate and carried out in parallel. $\left[{ }^{3} \mathrm{H}\right] \mathrm{cAMP}$ accumulation in the absence of quinpirole varied between 8000 and $13000 \mathrm{cpm}$ in individual experiments and was set at 100\%. (b) Assay conditions were the same as in panel a; stably transfected $\mathrm{PCI} 2$ cells expressing $\mathrm{D}_{2}$ receptors at $\sim 0.3$ (circles), 0.1 (triangles), and $0.02 \mathrm{pmol} / \mathrm{mg}$ (squares) were stimulated in the presence of I $\mu \mathrm{M}$ CGSI2680 (closed symbols) or forskolin (open symbols). (c) PCI2 cells were rendered quiescent by serum withdrawal for $16 \mathrm{~h}$ in the presence of adenosine deaminase ( $\mathrm{I} \mathrm{U} / \mathrm{ml}) ; 30 \mathrm{~min}$ after the addition of fresh medium containing adenosine deaminase (ADA), the cells received vehicle (lane ADA) or were stimulated by I $\mu$ M CGS2 I 680 (CGS), I 0 nM quinpirole, or the combination of CGS2 I 680 and quinpirole. GTP-liganded rap I was trapped by the addition of a fusion protein comprising GST and the rap-binding domain of ral(GDS); 30\% aliquots of the material recovered in the pull-down assay were applied to an SDS-polyacrylamide gel, transferred to nitrocellulose and immunoblotted for rap I; in the lane labeled lysate an appropriate amount of the detergent lysate from unstimulated cells was applied to the gel. The bar diagram summarizes the densitometric quantitation $(n=3)$; error bars indicate SD; $* p<0.05$ quinpirole + CGS21 680 vs CGS2 680 (Student's $t$-test).

cAMP formation by $30-40 \%$ (triangles in Figure 3a; open squares in Figure $3 \mathrm{~b})$. The $\mathrm{EC}_{50}(8.7 \pm 4.6 \mathrm{nM})$ was in the same range as that for the stimulating effect. PC12 cells were pretreated with pertussis toxin to block signaling via $G_{i} / G_{o}$. This pretreatment abolished both the ability of quinpirole to enhance cAMP formation in the presence of $\mathrm{A}_{2 \mathrm{~A}}$ agonist CGS21680 (squares in Figure 3a) and to reduce forskolinstimulated cAMP accumulation (diamonds in Figure 3a).

We also examined additional stably transfected PC12 cell clones that expressed higher levels of $\mathrm{D}_{2}$ receptors, namely $\sim 100$ and $300 \mathrm{fmol} / \mathrm{mg}$ (as assessed by binding of $\left[{ }^{125} \mathrm{I}\right]$ epidepride). In PC12 cells carrying higher receptor levels, quinpirole inhibited $\mathrm{A}_{2 \mathrm{~A}}$ agonist (closed circles and triangles in Figure $3 \mathrm{~b}$ ) and forskolin-stimulated cAMP accumlation to a roughly equivalent extent (open circles and triangles in Figure $3 \mathrm{~b}$ ). Finally, we also measured the effect of a quinpirole on $\mathrm{A}_{2 \mathrm{~A}}$-agonist-induced cAMP formation in HEK293 cells, in which the level of $\mathrm{D}_{2}$ receptor expression was reasonably comparable to that seen in PC12 cells (cf Figure 2a and c). In HEK293 cells, stimulation of the $\mathrm{D}_{2}$ dopamine receptor invariably caused inhibition of $\mathrm{A}_{2 \mathrm{~A}^{-}}$ receptor-induced cAMP accumulation. The transfection of HEK293 cells was only transient. However, the transfection efficiency was high (ie substantially $>50 \%$ ); this is also evident from the observation that forskolin-stimulated cAMP accumulation was inhibited by about $75 \%$ (righthand bars in Figure 2d).

Inhibition of cAMP accumulation is the expected response to $\mathrm{D}_{2}$ dopamine receptors. In the PC12 cell clone that expressed $\sim 60 \mathrm{fmol} / \mathrm{mg} \mathrm{D}_{2}$ receptors, we have there- 
a

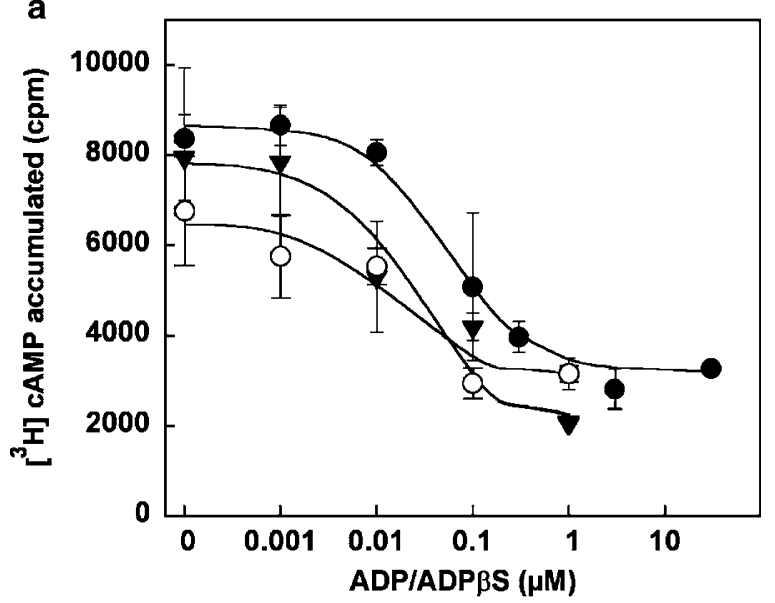

b

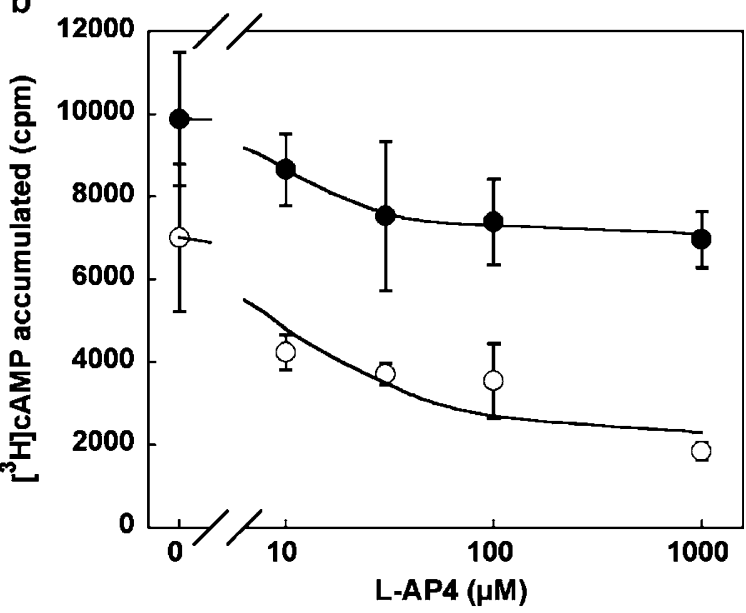

C

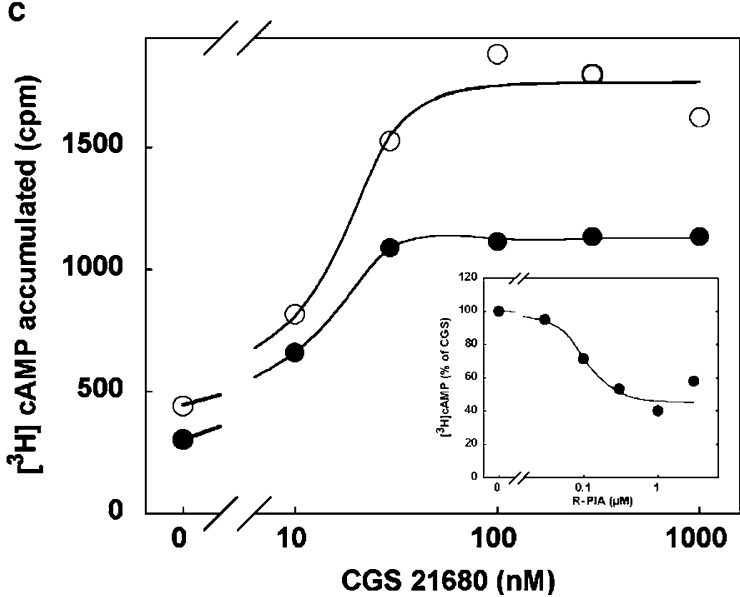

Figure 4 Inhibition of CAMP accumulation in $\mathrm{PCI} 2$ cells by the endogenously expressed $\mathrm{P} 2 \mathrm{y}$ receptor (a), and following stable expression of mGluR7A (b) and of the $A_{1}$ adenosine receptor (c). Assay conditions were as outlined in the legend to Figure 3. $(a, b)$ Cells were stimulated with I $\mu$ M CGS2I680 (closed symbols) or $25 \mu \mathrm{M}$ forskolin (open symbols); CAMP accumulation was inhibited by the concomitant addition of the indicated concentrations of ADP (panel a: circles), ADP $\beta$ S (panel a: triangles) and L-AP4 (panel b: circles). Data are means \pm SD $(n=3-5)$. (c) The concentration-response curve for CGS21680 was determined in the absence (open circles) and presence of 20 nM CPA (closed circles); data are from a representative experiment that was reproduced twice. Inset in panel c: Cells were stimulated with I $\mu$ M CGS2 1680; cAMP accumulation was inhibited by the concomitant addition of the indicated concentrations of R-PIA. fore employed an additional approach to obtain independent evidence for enhanced cAMP accumulation. This relied on Epac-induced activation of rap1. Epac, the guanine nucleotide exchange factor of the small $\mathrm{G}$ protein rap1, is directly controlled by cAMP (de Rooij et al, 1998); raising cellular cAMP levels thus leads to exchange of GTP for GDP on rap1 and the resulting GTP-liganded rap1 can be trapped-after cell lysis - by using the Rap-binding domain (RBD) of RalGDS as a bait (Franke et al, 1997). As expected, CGS21680 stimulated the accumulation of GTP-loaded rap1 (Figure 3c). In contrast, quinpirole per se did not have any appreciable effect (cf control lane ADA with lane quinpirole in Figure 3c). However, if PC12 cells were challenged with both CGS21680 and quinpirole, GTPbound rap1 accumulated to levels that significantly exceeded $(p<0.05$, Student's $t$-test $)$ those seen in the presence of CGS21680 alone (Figure 3c and d). Thus, the synergistic stimulation induced by the $\mathrm{D}_{2}$ agonist resulted in accumulation of cAMP over a range that was physiologically relevant because it was sensed by an intracellular cAMP-binding effector, namely Epac (de Rooij et al, 1998).

\section{Inhibition of cAMP Formation by other $\mathrm{G}_{\mathrm{i}} / \mathrm{G}_{\mathrm{o}}$-Coupled Receptors in PC12 Cells}

With the exception of the type IX isoform, all membranebound forms of mammalian adenylyl cyclase are activated by forskolin, albeit to a variable extent (Sunahara et al, 1996; Hanoune and Defer, 2001). The ability of the $D_{2}$ receptor to discriminate between forskolin-mediated and $\mathrm{A}_{2 \mathrm{~A}}$-receptor-mediated (ie $\mathrm{G} \alpha_{\mathrm{s}}$-mediated) activation of cAMP formation presumably reflects the net effect on enzyme isoforms that are susceptible to inhibition (ie via $\mathrm{G} \alpha_{\mathrm{i}}$ and/or $\mathrm{G} \alpha_{\mathrm{o}}$ and $\mathrm{G} \beta \gamma$ ) and costimulation (via $\mathrm{G} \beta \gamma$ ). We have tested if other $G_{i} / G_{o}$-coupled receptors also discriminated between forskolin- and $\mathrm{A}_{2 \mathrm{~A}}$-receptor-stimulated cAMP accumulation. PC12 cells endogenously express a $\mathrm{P}_{2 \mathrm{Y}}$ receptor that couples $\mathrm{G} \alpha_{\mathrm{i} / \mathrm{o}}$ and shares many pharmacological characteristics with the $\mathrm{P} 2 \mathrm{y}_{12}$ receptor (Unterberger et al, 2002). In both, the untransfected parent PC12 cells (Figure 4a) as well as in the PC12 cell lines stably expressing the $\mathrm{D}_{2}$ receptor (not shown), the physiological agonist ADP and $\mathrm{ADP} \beta \mathrm{S}$, an analog that is more resistant to metabolism (phosphorylation to ATP and dephosphorylation to AMP), inhibited the cAMP accumulation induced by CGS21680 with a potency in the submicromolar range. Forskolinstimulated activity was inhibited over a similar concentration range of $\mathrm{ADP} \beta \mathrm{S}$ and with similar efficacy, that is, by about $40-50 \%$.

The discrepancy between the $\mathrm{P} 2 \mathrm{y}$ receptor and the $\mathrm{D}_{2}$ receptor may have arisen from the difference between endogenous and heterologous expression. We have therefore also checked if the $\mathrm{A}_{2 \mathrm{~A}}$-receptor-dependent cAMP accumulation was enhanced or inhibited by two additional, heterologously expressed $\mathrm{G}_{\mathrm{i}} / \mathrm{G}_{\mathrm{o}}$-coupled receptors, namely the $A_{1}$ adenosine receptor and the mGluR7A. In stably transfected PC12 cells endowed with mGluR7A, the $\mathrm{A}_{2 \mathrm{~A}}$ adenosine receptor- and forskolin-induced cAMP formation was inhibited by the group III-specific metabotropic glutamate receptor agonist L-AP4 (Figure $4 \mathrm{~b}$ ). While the effect was seen over a similar concentration range, the inhibition of forskolin-stimulated cAMP accumulation was 
more pronounced than that induced by activation of the $\mathrm{A}_{2 \mathrm{~A}}$ adenosine receptor (Figure $4 \mathrm{~b}$ ). Similarly, in PC12 cells expressing the $A_{1}$ receptor at levels compatible with the endogenous expression in the CNS $(\sim 1 \mathrm{pmol} / \mathrm{mg}$, see Figure $1 \mathrm{~b}$ ), the $\mathrm{A}_{1}$ agonist CPA employed at the $\mathrm{A}_{1}$-selective concentration of $20 \mathrm{nM}$ blunted the stimulatory effect of the $\mathrm{A}_{2 \mathrm{~A}}$ agonist CGS21680 by about $30-40 \%$; this inhibition was also seen with R-PIA, another $\mathrm{A}_{1}$-selective agonist, and was uniform over the entire concentration-response curve for CGS21680 (Figure 4c). As expected, $\mathrm{A}_{1}$-selective agonists displayed biphasic concentration-response curves when tested in the presence of forskolin, namely an $A_{1}$-receptormediated inhibition of cAMP formation at low concentrations (by about 50\%) (data not shown) and an $\mathrm{A}_{2 \mathrm{~A}}$ adenosine receptor-dependent stimulation at high concentrations (not shown).

\section{Effects of $G_{i} / G_{0}$-Coupled Receptors on Voltage-Activated $\mathrm{Ca}^{2+}$ Currents in PC12 Cells}

In neuroendocrine cells $\mathrm{G}_{\mathrm{i}} / \mathrm{G}_{\mathrm{o}}$-coupled receptors inhibit voltage-activated $\mathrm{Ca}^{2+}$ currents, an effect that can also be reproduced in both differentiated and undifferentiated PC12 cells (Vartian and Boehm, 2001). We therefore investigated if quinpirole inhibited $\mathrm{Ca}^{2+}$ currents in $\mathrm{PC1} 2$

a

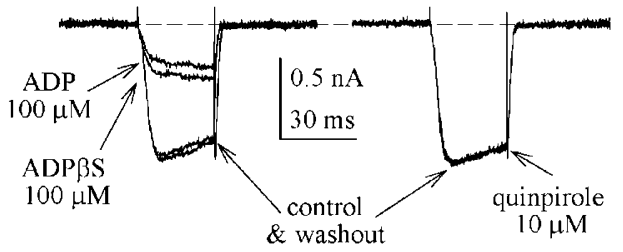

b

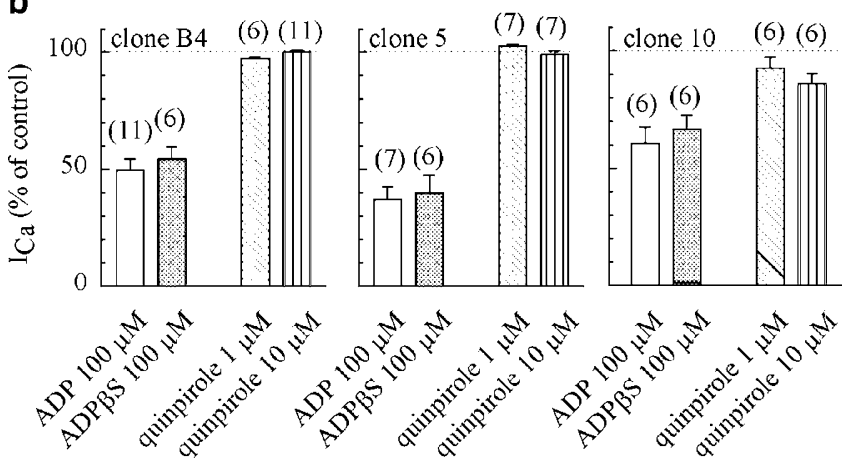

Figure 5 Regulation of voltage-activated $\mathrm{Ca}^{2+}$ currents by the endogenously expressed $\mathrm{P} 2 y$ receptor, and following stable expression of the human $\mathrm{D}_{2}$ dopamine receptor. Differentiated $\mathrm{PC} \mid 2$ cells were plated at low density and whole-cell currents were recorded at room temperature $\left(20-24^{\circ} \mathrm{C}\right) ; \mathrm{Ca}^{2+}$ currents were elicited by $30 \mathrm{~ms}$ depolarizations from a holding potential of -80 to $0 \mathrm{mV}$ before (control), during, and after (washout) application of the indicated receptor ligands. Panel a shows original traces for $\mathrm{PCI} 2$ cells stably expressing $\mathrm{D}_{2}$ dopamine receptors (clone B4), as an internal control, the endogenous $\mathrm{P} 2 y$ receptor was activated by ADP and the metabolically stable analog ADP $\beta$ S. Panel b summarizes the inhibitory effects of ADP, ADP $\beta$, and quinpirole in $\mathrm{PCI} 2$ cell clones that express the $D_{2}$ dopamine receptor at different levels (see Figures 2 and 3). The graphs show peak $\mathrm{Ca}^{2+}$ current amplitudes in the presence of these drugs (arithmetic means \pm SEM) as a percentage of the amplitudes in their absence. The number of cells investigated is indicated in parentheses.

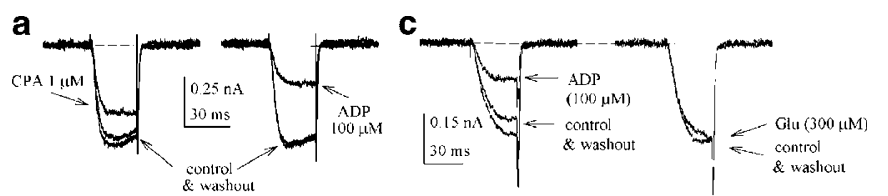

b

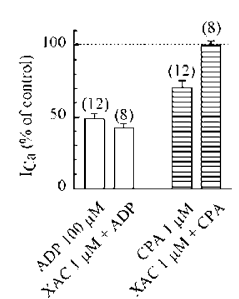

d

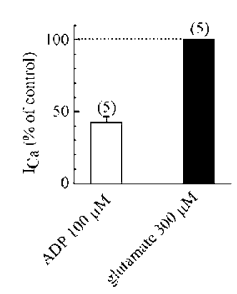

Figure 6 Regulation of voltage-activated $\mathrm{Ca}^{2+}$ currents by the endogenously expressed $\mathrm{P} 2 \mathrm{y}$ receptor, and following stable expression of the $A_{\text {l }}$ adenosine receptor $(a, b)$ and the mGLuR7A (c, d). Recording conditions were as in Figure 5. Panels a and $\mathrm{c}$ show original traces for $\mathrm{PCI} 2$ cells heterologously expressing the indicated receptors. Panels $b$ and $d$ summarize the inhibitory effects of ADP, CPA, and glutamate. Panel $b$ also documents the effect of the adenosine receptor antagonist XAC. The graphs show peak $\mathrm{Ca}^{2+}$ current amplitudes in the presence of these drugs (arithmetic means \pm SEM) as a percentage of the amplitudes in their absence. The number of cells investigated is indicated in parentheses.

cells that stably expressed the $\mathrm{D}_{2}$ dopamine receptor. In these transfected cells, the $\mathrm{P}_{2 \mathrm{Y}}$ agonists $\mathrm{ADP}$ and $\mathrm{ADP} \beta \mathrm{S}$, which were employed as positive controls, decreased the $\mathrm{Ca}^{2+}$ current by $50 \%$ (Figure $5 \mathrm{a}$ and b). In contrast, quinpirole had little or no effect on the $\mathrm{Ca}^{2+}$ current even when applied at the very high concentration of $10 \mu \mathrm{M}$ (Figure 5a and b). Again, we ruled out that this discrepancy between endogenously present $\mathrm{P}_{2 \mathrm{Y}}$ receptor and heterologously introduced $\mathrm{D}_{2}$ receptor was accounted for by the forced expression; in PC12 cells that heterologously expressed the $A_{1}$ adenosine receptor, the receptor agonist CPA decreased the $\mathrm{Ca}^{2+}$ current by $30 \%$, an effect that was totally abolished by addition of the adenosine receptor antagonist XAC at $1 \mu \mathrm{M}$ (Figure $6 \mathrm{a}$ and $\mathrm{b}$ ). XAC did not affect the ADP-mediated inhibition of $\mathrm{Ca}^{2+}$ current in PC12 that carried $A_{1}$ adenosine receptors. Similarly, the effect of CPA was absent in cells that did not express the $A_{1}$ adenosine receptor (not shown). It is worth pointing out that the discrepancy between the $A_{1}$ adenosine receptor and the $\mathrm{D}_{2}$ dopamine receptor can neither be accounted for by the low expression levels of the $\mathrm{D}_{2}$ dopamine receptor nor by clonal variation. (i) Even in clone 10 , in which $\mathrm{D}_{2}$ receptor levels clearly exceeded those of the $A_{1}$ receptor, there was only a very modest inhibition of $\mathrm{Ca}^{2+}$ currents (by some $10 \%$ at most; see Figure 5b, right-hand panel). (ii) The response to ADP was not significantly different in the two cell lines ( $\sim 40-50 \%$ inhibition in the presence of ADP, cf Figure 5b, right-hand panel, and Figure $6 \mathrm{~b}$ ). Finally, the deficiency was not restricted to the $\mathrm{D}_{2}$ receptor. Similar to PC12-D2 cells, upon agonist stimulation, mGluR7A failed to inhibit $\mathrm{Ca}^{2+}$ currents (Figure $6 \mathrm{c}$ and $\mathrm{d}$ ) although cAMP accumulation was inhibited (cf Figure $4 b$ ).

\section{DISCUSSION}

A specific interaction of the $A_{2 A}$ adenosine receptor and the $\mathrm{D}_{2}$ dopamine receptor has repeatedly been evoked to 
account for the mutual antagonism that can be observed in striatopallidal neurons (Lindskog et al, 1999). This assumption is based on both observations in membranes prepared from the striatum (Ferré et al, 1991b) as well as from transfected cells (Dasgupta et al, 1996; Kull et al, 1999), in which $\mathrm{A}_{2 \mathrm{~A}}$ agonists blunted high-affinity agonist binding to $\mathrm{D}_{2}$ receptors. However, in PC12 cells, we did not detect any appreciable inhibition of $\mathrm{D}_{2}$ agonist binding. In contrast, our present experiments demonstrate that $A_{2 A}$ and $D_{2}$ receptors can also synergize in the regulation of their prototypic common effector, adenylyl cyclase. Thus, antagonism of $\mathrm{D}_{2}$-receptor-mediated responses by activation of $\mathrm{A}_{2 \mathrm{~A}}$ receptor (and vice versa) is not a universal phenomenon. In fact, a synergistic activation of cAMP-dependent signaling by $A_{2 A}$ and $D_{2}$ receptors has recently also been reported in NG108-15 cells that stably expressed the $D_{2}$ receptor (Yao et al, 2002). Our observations also indicate that the expression level of the $\mathrm{D}_{2}$ receptor is important in determining whether this receptor pair raises cAMP synergistically. Low levels of $\mathrm{D}_{2}$ receptors favored coactivation while at higher expression levels the $A_{2 A}$-induced cAMP response was inhibited. The concentration of $\mathrm{D}_{2}$ receptors in PC12 cell membranes was within the range found in various brain areas; nevertheless, it is not possible to extrapolate these numbers and predict the response of $\mathrm{D}_{2}$ receptor containing neurons because the local concentration at pre- or postsynaptic specializations is not known. Regardless of these limitations, the physiological relevance of our observations is underscored by the recent study of Yao et al (2002); this work also demonstrates that $\mathrm{D}_{2}$ and $\mathrm{A}_{2 \mathrm{~A}}$ receptors synergize to activate cAMP-dependent signaling in rat hippocampal neurons and in the nucleus accumbens. The synergism exerted in the latter region apparently supports sustained alcohol consumption (Yao et al, 2002).

Synergistic stimulation of adenylyl cyclase activity is to be expected because most isoforms of adenylyl cyclase have the capacity to function as coincidence detectors (Sunahara et al, 1996; Hanoune and Defer, 2001); for example, adenylyl cyclase type-I and to a lesser extent type-VIII are synergistically activated by $\mathrm{G} \alpha_{\mathrm{s}}$ and $\mathrm{Ca}^{2+}$ /calmodulin (Xia and Storm, 1997). Similarly, the activation of adenylyl cyclase type-II, -IV, and -VII by G $\beta \gamma$ is conditional on the presence of activated $\mathrm{G} \alpha_{\mathrm{s}}$ (Taussig et al, 1994). In PC12 cells, the potentiating effect of the $\mathrm{D}_{2}$ agonist (and its inhibitory action) was abrogated upon pretreatment of the cells with pertussis toxin. Thus both stimulation and inhibition depended on the presence of $G_{i}$ or $G_{o}$. Most cells express several adenylyl cyclase isoforms (Hanoune and Defer, 2001). This is true for PC12 cells where the type-VI enzyme is abundant but not the only isoform (Chern et al, 1995). Adenylyl cyclase type-VI and $-\mathrm{V}$ are inhibited by $\mathrm{Ca}^{2+}$. In reconstitution experiments, they are also inhibited by $\mathrm{G} \alpha_{i}$ subunits, but $\mathrm{G} \beta \gamma$ has no appreciable effect (Taussig et al, 1994; Kudlacek et al, 2001). In contrast, $\mathrm{D}_{2}$-receptormediated stimulation was contingent on the formation of active $\mathrm{G} \alpha_{\mathrm{s}}$ by the $\mathrm{A}_{2 \mathrm{~A}}$ adenosine receptor; forskolin-induced cAMP accumulation was invariably inhibited by the $D_{2}$ receptor. For a parsimonious explanation, the synergism is most readily accounted for by assuming that $G$ protein subunits, that is, GTP-liganded $\mathrm{G} \alpha_{\mathrm{s}}$ generated by activation of the $A_{2 A}$ receptor and $G \beta \gamma$ generated by activation of the
$\mathrm{D}_{2}$ receptor, converge at the level of adenylyl cyclase. Hence, the likely candidate mechanism that underlies the costimulatory action of the $\mathrm{D}_{2}$ receptor is $\mathrm{G} \beta \gamma$-dependent activation of a type-II-like adenylyl cyclase. In fact, protein fragments that scavenge free $\mathrm{G} \beta \gamma$ are capable of eliminating the synergism between $\mathrm{D}_{2}$ and $\mathrm{A}_{2 \mathrm{~A}}$ receptors in both NG108-15 cells and neurons (Yao et al, 2002).

At low expression levels, $\mathrm{D}_{2}$ receptors supported synergistic activation of $\mathrm{A}_{2 \mathrm{~A}}$-receptor-dependent cAMP accumulation; the effect was lost at higher expression levels and a robust inhibition was seen. This observation is consistent with the combined action on a type-II- and a type VI-like adenylyl cyclase isoform. The conditional activation of a type-II-like adenylyl cyclase requires concentrations of $\mathrm{G} \beta \gamma$ in the low nanomolar range (Taussig et al, 1993). In contrast, inhibition of isoforms V and VI by activated $G \alpha_{i}$ requires concentrations that are about 10-fold higher (Taussig et al, 1994). Thus $\mathrm{G} \beta \gamma$ generated at low $\mathrm{D}_{2}$ receptor concentrations may suffice for sensitization of a type-II-like adenylyl cyclase, whereas at high receptor levels the amounts of active $G \alpha_{i}$ reach the threshold to support inhibition of the abundant type-VI enzyme in PC12 cells.

In the clones that express high receptor numbers, stimulation of cAMP accumulation was to be expected at low occupancy of the receptor by the $\mathrm{D}_{2}$ agonist. In some experiments, this was indeed the case. However, it was not seen reproducibly. The limits of detection can be calculated by Monte Carlo simulation by using the parameters obtained at high and low receptor expression, that is, 1.3fold maximum stimulation and maximum inhibition by $60-$ $70 \%$. The synthetic data were generated with a realistic random error of 5-10\%. Under these assumptions, an initial stimulation was only detected reliably if $\mathrm{EC}_{50}$ (for stimulation of cAMP accumulation) and $\mathrm{IC}_{50}$ (for inhibition of cAMP accumulation) differed by $>100$-fold (for an analogous analysis, see Freissmuth et al, 1987). Thus, if receptor occupancy and effect were directly related, the expression levels would have to be increased 100-fold in order to detect the stimulation at low agonist concentrations (in the presence of the ensuing inhibition at higher receptor occupancy). In other words, inhibition would be reliably detected only if $\mathrm{D}_{2}$ receptor expression levels were raised to $>6 \mathrm{pmol} / \mathrm{mg}$.

The synergism was restricted to the pair $\mathrm{A}_{2 \mathrm{~A}}$ receptor $/ \mathrm{D}_{2}$ receptor and not seen if the endogenous $\mathrm{P}_{2 \mathrm{Y}}$ receptor or the transfected $\mathrm{A}_{1}$ receptor and mGluR7A were activated. Obviously, the $A_{1}$ adenosine receptor was expressed at levels that far exceeded those at which synergism was seen with the $\mathrm{D}_{2}$ dopamine receptor. Contrary to the $\mathrm{D}_{2}$ receptor, mGluR7A only supported inhibition of cAMP formation. Similarly, when present at $1 \mathrm{pmol} / \mathrm{mg}$, the $A_{1}$ receptor only inhibited $\mathrm{A}_{2 \mathrm{~A}}$-dependent cAMP accumulation by $\sim 50 \%$. In contrast, when present at $0.3 \mathrm{pmol} / \mathrm{mg}$, the $\mathrm{D}_{2}$ receptor blunted the $\mathrm{A}_{2 \mathrm{~A}}$ response by $70 \%$. The most plausible explanation for these discrepancies is to assume that receptors (and effectors) are segregated rather than freely diffusible and that $\mathrm{A}_{2 \mathrm{~A}}$ and $\mathrm{D}_{2}$ receptors are closely associated. In fact, complexes of these two receptors have been observed that are sufficiently stable to allow for coimmunoprecipitation of $\mathrm{D}_{2}$ receptors with $\mathrm{A}_{2 \mathrm{~A}}$ receptors (Hillion et al, 2002). 
Taken together, our data are consistent with the concept that the $D_{2}$ receptor and the $A_{2 A}$ receptor form a unique pair when present within the membrane of a given cell (Ferré et al, 1991b; Dasgupta et al, 1996; Kull et al, 1999). However, the interaction between these two receptors does not necessarily result in mutual antagonism. Finally, the emphasis on adenylyl cyclase regulation and on $G$ protein coupling may detract from alternative signaling pathways. Although $\mathrm{A}_{2 \mathrm{~A}}$ receptors do not raise cAMP levels in striata of mice that are deficient in $\mathrm{D}_{2}$ receptors (Zahniser et al, 2000), $A_{2 \mathrm{~A}}$ antagonists still partially restore locomotor activity in these animals. This indicates that neither changes in cAMP nor the presence of $\mathrm{D}_{2}$ receptors are required to account for their beneficial effect on animal models of Parkinson's disease (Aoyama et al, 2000; Zahniser et al, 2000; Chen et al, 2001). In fact, the $A_{2 A}$ receptor has the capacity to signal in a manner independent of $\mathrm{G} \alpha_{\mathrm{s}}$ (Sexl et al, 1997; Seidel et al, 1999).

\section{ACKNOWLEDGMENTS}

We thank Dr E Ogris for a kind gift of antibody 16B12. This work was supported by grants from the Austrian Science Foundation (FWF) and the European Community.

\section{REFERENCES}

Akhondzadeh S, Shasavand E, Jamilian H, Shabestari O, Kamalipour A (2000). Dipyridamole in the treatment of schizophrenia: adenosine-dopamine receptor interactions. J Clin Pharm Ther 25: 131-137.

Arslan G, Kull B, Fredholm BB (1999). Signaling via $A_{2 A}$ adenosine receptor in four PC12 cell clones. Naunyn Schmiedebergs Arch Pharmacol 359: 28-32.

Aoyama S, Kase H, Borrelli E (2000). Rescue of locomotor impairment in dopamine $\mathrm{D}_{2}$ receptor-deficient mice by an adenosine $\mathrm{A}_{2 \mathrm{~A}}$ receptor antagonist. J Neurosci 20: 5848-5852.

Ascherio A, Zhang SM, Hernan MA, Kawachi I, Colditz GA, Speizer FE et al (2001). Prospective study of caffeine consumption and risk of Parkinson's disease in men and women. Ann Neurol 50: 56-63.

Beindl W, Mitterauer T, Hohenegger M, IJzerman AP, Nanoff C, Freissmuth M (1996). Inhibition of receptor-G protein coupling by suramin analogs. Mol Pharmacol 50: 415-423.

Benedetti MD, Bower JH, Maraganore DM, McDonnell SK, Peterson BJ, Ahlskog JE et al (2000). Smoking, alcohol, and coffee consumption preceding Parkinson's disease: a casecontrol study. Neurology 55: 1350-1358.

Bofill-Cardona E, Kudlacek O, Yang Q, Ahorn H, Freissmuth M, Nanoff $C$ (2000). Binding of calmodulin to the $D_{2}$-dopamine receptor reduces receptor signaling by arresting the $G$ protein activation switch. J Biol Chem 275: 32672-32680.

Chen JF, Moratalla R, Impagnatiello F, Grandy DK, Cuellar B, Rubinstein $M$ et al (2001). The role of the $D_{2}$ dopamine receptor $\left(\mathrm{D}_{2} \mathrm{R}\right)$ in $\mathrm{A}_{2 \mathrm{~A}}$ adenosine receptor $\left(\mathrm{A}_{2 \mathrm{~A}} \mathrm{R}\right)$-mediated behavioral and cellular responses as revealed by $A_{2 A}$ and $D_{2}$ receptor knockout mice. Proc Natl Acad Sci USA 98: 1970-1975.

Chern Y, Chiou JY, Lai HL, Tsai MH (1995). Regulation of adenylyl cyclase type VI activity during desensitization of the $\mathrm{A}_{2 \mathrm{~A}}$ adenosine receptor-mediated cyclic AMP response: role for protein phosphatase 2A. Mol Pharmacol 48: 1-8.

Dasgupta S, Ferré S, Kull B, Hedlund PB, Finnman UB, Ahlberg S et al (1996). Adenosine $\mathrm{A}_{2 \mathrm{~A}}$-receptors modulate the binding characteristics of dopamine D2 receptors in stably cotransfected fibroblast cells. Eur J Pharmacol 316: 325-331.
Dassesse D, Massie A, Ferrari R, Ledent C, Parmentier M, Arckens L et al (2001). Functional striatal hypodopaminergic activity in mice lacking adenosine $A_{2 A}$ receptors. J Neurochem 78: 183-198.

de Rooij J, Zwartkruis FJ, Verheijen MH, Cool RH, Nijman SM, Wittinghofer A et al (1998). Epac is a Rap1 guanine-nucleotideexchange factor directly activated by cyclic AMP. Nature 396: 474-477.

ElFar O, Bofill-Cardona E, Airas JM, O'Connor V, Boehm S, Freissmuth $M$ et al (2001). Mapping of the calmodulin and G $\beta \gamma$ binding domains within the C-terminal region of the metabotropic glutamate receptor 7A. J Biol Chem 275: 30662-30669.

Ferré S, Fredholm BB, Morelli M, Popoli P, Fuxe K (1997). Adenosine-dopamine receptor-receptor interactions as an integrative mechanism in the basal ganglia. Trends Neurosci 20: $482-487$.

Ferré S, Rubio A, Fuxe K (1991a). Stimulation of adenosine $A_{2}$ receptors induces catalepsy. Neurosci Lett 30: 162-164.

Ferré S, von Euler G, Johansson B, Fredholm BB, Fuxe K (1991b). Stimulation of high-affinity adenosine $A_{2}$ receptors decreases the affinity of dopamine $\mathrm{D}_{2}$ receptors in rat striatal membranes. Proc Natl Acad Sci USA 88: 7238-7241.

Franke B, Akkerman JWN, Bos JL (1997). Rapid $\mathrm{Ca}^{2+}$-mediated activation of Rap1 in human platelets. EMBO J 16: 252-259.

Fredholm BB, Battig K, Holmen J, Nehlig A, Zvartau EE (1999). Actions of caffeine in the brain with special reference to factors that contribute to its widespread use. Pharmacol Rev 51: 83-133.

Freissmuth M, Hausleithner V, Tuisl E, Nanoff C, Schütz W (1987). Glomeruli and microvessels of the rabbit kidney contain both A1- and A2-adenosine receptors. Naunyn Schmiedeberg's Arch Pharmacol 335: 438-444.

Grondin R, Bedard PJ, Hadj Tahar A, Grégoire L, Mori A, Kase H (1999). Antiparkinsonian effect of a new selective adenosine $A_{2 A^{-}}$ receptor antagonist in MPTP-treated monkeys. Neurology 52: 1673-1677.

Hanoune J, Defer N (2001). Regulation and role of adenylyl cyclase isoforms. Annu Rev Pharmacol Toxicol 41: 145-174.

Hauber W, Neuscheler P, Nagel J, Müller CE (2001). Catalepsy induced by a blockade of dopamine $\mathrm{D}_{1}$ or $\mathrm{D}_{2}$ receptors was reversed by a concomitant blockade of adenosine $\mathrm{A}_{2 \mathrm{~A}}$ receptors in the caudate-putamen of rats. Eur J Neurosci 14: 1287-1293.

Hillion J, Canals M, Torvinen M, Casado V, Scott R, Terasmaa A et al (2002). Coaggregation, cointernalization, and codesensitization of adenosine $\mathrm{A}_{2 \mathrm{~A}}$-receptors and dopamine $\mathrm{D}_{2}$ receptors. $J$ Biol Chem 277: 18091-18097.

Jockers R, Linder M, Hohenegger M, Nanoff C, Bertin B, Strosberg $\mathrm{AD}$ et al (1994). Species differences in the $\mathrm{G}$ protein selectivity of the human and bovine $\mathrm{A}_{1}$-adenosine receptor. J Biol Chem 269: 32077-32084.

Klinger M, Kuhn M, Just H, Stefan E, Palmer T, Freissmuth M et al (2002). Removal of the carboxy terminus of the $A_{2 A}$-adenosine receptor blunts constitutive activity: differential effect on cAMP accumulation and MAP kinase stimulation. Naunyn Schmiedeberg's Arch Pharmacol 366: 287-298.

Kudlacek O, Mitterauer T, Nanoff C, Hohenegger M, Tang W-J, Freissmuth $\mathrm{M}$ et al (2001). Inhibition of adenylyl and guanylyl cyclase isoforms by the antiviral drug foscarnet. J Biol Chem 275: 3010-3016.

Kull B, Ferré S, Arslan G, Svenningsson P, Fuxe K, Owman C et al (1999). Reciprocal interactions between adenosine $A_{2 A}$ and dopamine $D_{2}$ receptors in Chinese hamster ovary cells cotransfected with the two receptors. Biochem Pharmacol 58: 10351045.

Lindskog M, Svenningsson P, Fredholm BB, Greengard P, Fisone G (1999). Activation of dopamine $\mathrm{D}_{2}$ receptors decreases DARPP32 phosphorylation in striatonigral and striatopallidal projection neurons via different mechanisms. Neuroscience 88: 1005-1008.

Pinna A, Wardas J, Cozzolino A, Morelli M (1999). Involvement of adenosine $A_{2 A}$ receptors in the induction of $c-$ fos expression 
by clozapine and haloperidol. Neuropsychopharmacology 20: $44-51$.

Richardson PJ, Kase H, Jenner PG (1997). Adenosine $A_{2 A}$ receptor antagonists as new agents for the treatment of Parkinson's disease. Trends Pharmacol Sci 18: 338-344.

Ross GW, Abbott RD, Petrovitch H, Morens DM, Grandinetti A, Tung KH et al (2000). Association of coffee and caffeine intake with the risk of Parkinson disease. JAMA 283: 2674-2679.

Salomon Y (1991). Cellular responsiveness to hormones and neurotransmitters: conversion of $\left[{ }^{3} \mathrm{H}\right]$ adenine to $\left[{ }^{3} \mathrm{H}\right] \mathrm{cAMP}$ in cell monolayers, cell suspensions, and tissue slices. Methods Enzymol 195: 22-28.

Seidel MG, Klinger M, Freissmuth M, Höller C (1999). Activation of MAP kinase by the $\mathrm{A}_{2 \mathrm{~A}}$-adenosine receptor via a rap1-dependent and via a p21 ${ }^{\text {ras }}$-dependent pathway. J Biol Chem 274: 2583335841.

Sexl V, Mancusi G, Höller C, Gloria-Maercker E, Schütz W, Freissmuth M (1997). Stimulation of the mitogen-activatedprotein kinase (MAP kinase) via the $\mathrm{A}_{2 \mathrm{~A}}$-adenosine receptor in primary human endothelial cells. J Biol Chem 272: 5792-5799.

Shigemoto R, Kulik A, Roberts JD, Ohishi H, Nusser Z, Kaneko T et al (1996). Target-cell-specific concentration of a metabotropic glutamate receptor in the presynaptic active zone. Nature 378: 96-98.

Stowell JN, Craig AM (1999). Axon/dendrite targeting of metabotropic glutamate receptors by their cytoplasmic carboxyterminal domains. Neuron 22: 525-536.

Sunahara RK, Dessauer CW, Gilman AG (1996). Complexity and diversity of mammalian adenylyl cyclases. Annu Rev Pharmacol Toxicol 36: 461-480.
Svenningsson P, Le Moine C, Fisone G, Fredholm BB (1999). Distribution, biochemistry and function of striatal adenosine $\mathrm{A}_{2 \mathrm{~A}}$-receptors. Prog Neurobiol 59: 355-396.

Taussig R, Tang WJ, Hepler JR, Gilman AG (1994). Distinct patterns of bidirectional regulation of mammalian adenylyl cyclases. J Biol Chem 269: 6093-6100.

Taussig R, Quarmby LM, Gilman AG (1993). Regulation of purified type I and type II adenylyl cyclases by $\mathrm{G}$ protein $\beta \gamma$-subunits. $J$ Biol Chem 268: 9-12.

Unterberger U, Moskvina E, Scholze T, Freissmuth M, Boehm S (2002). Inhibition of adenylyl cyclase by neuronal P2Y receptors. Br J Pharmacol 135: 673-684.

Vartian N, Boehm S (2001). P2Y receptor-mediated inhibition of voltage-activated $\mathrm{Ca}^{2+}$ currents in PC12 cells. Eur J Neurosci 13: 899-908.

Waldhoer M, Bofill-Cardona E, Milligan G, Freissmuth M, Nanoff C (1998). Differential uncoupling of $A_{1}$-adenosine and $D_{2}$ dopamine receptors by suramin and di-demethylated suramin (NF037). Mol Pharmacol 53: 808-818.

Xia Z, Storm DR (1997). Calmodulin-regulated adenylyl cyclases and neuromodulation. Curr Opin Neurobiol 7: 391-396.

Yao L, Arolfo MP, Dohrman DP, Jiang Z, Fan P, Fuchs S et al (2002). Dimers mediate synergy of dopamine D2 and adenosine A2 receptor-stimulated PKA signaling and regulate ethanol consumption. Cell 109: 733-743.

Zahniser NR, Simosky JK, Mayfield RD, Negri CA, Hanania T, Larson GA et al (2000). Functional uncoupling of adenosine $A_{2 A}$ receptors and reduced response to caffeine in mice lacking dopamine $\mathrm{D}_{2}$ receptors. J Neurosci 20: 5949-5957. 